\title{
Sexual Behaviour, Sero-Status Disclosure and Willingness to Disclose Status among HIV Positive Male Patients Receiving Care in Hospitals in Imo State, Nigeria
}

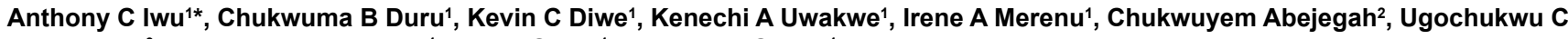
Madubueze $^{3}$, Emmanuel U Ndukwu ${ }^{1}$, Ikechi Ohale $^{1}$ and Martin Okolie ${ }^{1}$

${ }^{1}$ Department of Community Medicine, Imo State University, Owerri, Imo State, Nigeria

${ }^{2}$ Department of Community Medicine, Irrua Specialist Teaching Hospital, Irrua, Edo State, Nigeria

${ }^{3}$ Department of Community Medicine, Federal Teaching Hospital, Abakaliki, Nigeria

\section{Abstract}

Background: The non-disclosure of HIV positive status has most often been accompanied by risky sexual behaviours which is a complex relationship that facilitates the transmission of sexually transmitted diseases such as HIV.

Objective: To determine sexual behaviour, levels of sero-status disclose and willingness to disclose; and the socio-demographic determinants of disclosure and willingness to disclose among HIV positive male patients receiving care in hospitals in Imo State, Nigeria.

Methods: A cross sectional analytical design using a simple random sampling technique to select 422 HIV male patients attending the adult HIV clinics of two major hospitals. Data was collected using a pretested, semi structured questionnaire. Descriptive statistics were presented using frequencies and summary indices. Chi square statistics were computed to determine significant relationships and binary logistic regression was used to determine predictors of disclosure and willingness to disclose. A p-value of $\leq 0.05$ was considered significant.

Results: A majority of the respondents were either traders or artisans $(54.6 \%)$ with a mean age of $32.0 \pm 2.0$ years. The results revealed that more than one third of the respondents had two or more sexual partners $(35.5 \%)$, less than one quarter correctly and consistently use condoms (23.3\%) and close to one third had not disclosed their HIV positive status (31.7\%); of which, less than two fifths are now willing to disclose (37.8\%). It was further revealed that married HIV positive male patients who are traders or artisans above the age of 30 years with monthly income levels less than $N 40,000(\$ 110)$ and living in an urban or semi urban area with family members or other people, were significantly more likely to have disclosed their HIV positive status. Similarly, HIV positive male patients who had not disclosed their status, but are artisans aged above 30 years, were significantly more likely to be willing now to disclose their HIV positive status.

Conclusion: To be successful in our efforts of HIV prevention with respect to facilitating disclosure, it is important to design and implement interventions that are tailored to the specific circumstances and characteristics of the individual.

Keywords: Sexual behaviour; Sero-status disclosure; Willingness to disclose; HIV; Nigeria

\section{Introduction}

Human Immunodeficiency Virus/Acquired Immunodeficiency Syndrome (HIV/AIDS) still remains a potentially fatal transmissible disease of the immune system and a significant threat to the quality of life. The role of HIV counselling, testing and disclosure linked with the timely uptake of antiretroviral drugs has been significant in changing HIV infection to a progressively chronic manageable disease with the potential of living a long healthy and productive life.

The global and regional impact of HIVAIDS is gradually and decreasingly being felt due to the increased efforts in prevention and control activities. Globally, since 2010, though the number of people living with HIV increased to 36.7 million in 2015 with new infections remaining fairly constant, there has been an associated decrease of $27 \%$ in AIDS related deaths accompanied by an increase of $127 \%$ in the number of people now receiving antiretroviral drugs in 2015 [1].

In Western and Central Africa, only $36 \%$ and $28 \%$ of people living with HIV know their status and are receiving antiretroviral treatment respectively with an estimated $60 \%$ of all new infections in 2015 within the region, occurring in Nigeria [2].

Sexual behaviour involves a complex relationship of individual desires, socioeconomic, cultural and environmental factors which facilitates HIV transmission and other sexually transmitted diseases; and therefore, sexual behaviour remains the primary target of HIV/ AIDS prevention efforts globally [3]. Furthermore, non-disclosure of HIV status has most often been accompanied by risky sexual behaviour $[4,5]$; and as such, there has been concerted efforts to raise awareness and accomplish safer sexual behavioural practices.

Patients' awareness of their HIV status is critical to the disclosure process and this awareness is predicated on the uptake of HIV counselling and testing (HCT). Disclosure of HIV status, though, is a complex and challenging process, efforts should be focused on effectively addressing it especially in Africa; as disclosure rates are

*Corresponding author: Anthony C Iwu, Department of Community Medicine Imo State University, Owerri, Imo State, Nigeria; Tel: 234-8033483968; E-mail: iwuchinedu@yahoo.com

Received July 01, 2017; Accepted July 13, 2017; Published July 20, 2017

Citation: Iwu AC, Duru CB, Diwe KC, Uwakwe KA, Merenu IA, et al. (2017) Sexua Behaviour, Sero-Status Disclosure and Willingness to Disclose Status among HIV Positive Male Patients Receiving Care in Hospitals in Imo State, Nigeria. J AIDS Clin Res 8: 711. doi: 10.4172/2155-6113.1000711

Copyright: (c) 2017 Iwu AC, et al. This is an open-access article distributed under the terms of the Creative Commons Attribution License, which permits unrestricted use, distribution, and reproduction in any medium, provided the original author and source are credited. 
lower in developing countries when compared to developed countries with the proportion of people with the intention to disclose even higher than those that actually disclose [6].

In Africa, World Health Organization (WHO) estimated that $52 \%$ of People living with the virus disclose their status to their sexual partners [7], also a review of sub-Saharan African studies by Medley et al. [6] reported disclosure rates ranging from $17 \%$ to $86 \%$ and even more recent studies in Ethiopia reported rates above $90 \%[4,8]$. Although, with the passage of time, the rates of HIV status disclosure appears to increase; notwithstanding, non-disclosure at any given point in time, still puts HIV negative sexual partners in sero-discordant relationships at an increased risk of contracting HIV because they are unaware of their partner's HIV positive status [6,9].

Especially among Africans, the disclosure of a positive HIV status can be often characterized as a double edged sword where disclosure can either promote or enhance physical, social and psychological wellbeing or result in discrimination, stigmatization, rejection, abandonment, loss of employment, emotional and physical abuse especially directed at women and other negative social consequences [9-11]. In spite of this, disclosure remains an integral part of prevention and control within the continuum of the HIV care process.

Furthermore, promoting and encouraging HIV positive partners in sero-discordant relationships to disclose their status, remains an important component of prevention that results in the adoption of preventive behaviours such as partner uptake of HCT and condom use [4]; and also, where in the event of disclosure, the negative partner can refuse sex or only participate in safe sex or significantly reduce the practice of risky sexual acts $[12,13]$. Positive health outcomes, have also been associated with disclosure of a positive status, resulting in stress reduction and invariably, improvement in immune function linked with long term higher levels of CD4 cell counts [14,15].

HIV status disclosure rates appear to differ and vary with regard to the target of disclosure, motivations and gender; where men in one instance, were more likely to disclose their status to their sexual partners and brothers and women to their sisters [16] and in another instance, where the men were more likely to disclose to their wives rather than any family member and the women, to a family member or to a particular social support network member [17,18]. Amongst varying motivations, men, in the absence of likely stigmatization and discrimination, may be driven by the desire to protect their uninfected spouses, so that they can care for their children in case of death and for the women, in the absence of fear of domestic violence, abuse and abandonment, may be driven by the hope that their spouse may consider preventive measures such as the use of condom [19].

Motivations are driving forces for both disclosure and non-disclosure and the associated motivational circumstances are influenced by the individual's socio-demographic, economic and environmental factors. Therefore, determining the relationships of these factors, and in this case, the socio-demographic characteristics with respect to disclosure and the willingness to disclose, will provide better understanding of these motivations with the intention of developing tailored specific strategies, aimed at promoting and encouraging disclosure by HIV male patients to their sexual partners. This will constitute another important step in the prevention and control of HIV transmission.

\section{Methodology}

\section{Study area}

The study was conducted within the adult HIV clinics of Imo State
University Teaching Hospital, Orlu (IMSUTH) situated in Orlu Local Government Area (LGA) and Holy Rosary Hospital, Emekuku situated in Owerri North LGA in Imo State, South Eastern Nigeria. Orlu LGA is one of the 12 LGAs that comprise Imo West Senatorial zone and occupies an area of $132.9 \mathrm{~km}^{2}$ with a population density of about 1,074 persons $/ \mathrm{km}^{2}$. Owerri North LGA is one of the 9 LGAs that comprise Imo East Senatorial zone and occupies an area of $200 \mathrm{~km}^{2}$ with a population density of about 882 persons $/ \mathrm{km}^{2}$ [20]. Imo State University Teaching Hospital, Orlu is a comprehensive training, research and health care delivery tertiary institution and Holy Rosary Hospital, Emekuku is a general hospital with departments in medicine, general surgery, paediatrics, obstetrics and gynaecology. It is a training centre for General Nursing, Midwifery and Medical Laboratory Technology.

\section{Study population/study design/selection criteria}

The study population comprised adult male HIV infected patients accessing care from the HIV clinics of Imo State University Teaching Hospital and Holy Rosary Hospital, Emekuku. The study design was a hospital based cross sectional analytical survey. The inclusion criteria for enrolment into the survey after informed consents were; any adult male HIV patients that are clinically stable and receiving care from the HIV clinics for at least 6 months. Exclusion criteria; any HIV patient with debilitating comorbidities.

\section{Sample size estimation}

The minimum sample size was calculated using the Cochrane formula [21].

$$
\mathrm{n}=\frac{\mathrm{Z}^{2} \mathrm{pq}}{\mathrm{d}^{2}}
$$

When $\mathrm{n}=$ minimum sample size, $\mathrm{Z}=$ Standard normal deviate corresponding to $5 \%$ significant level,

$\mathrm{p}=$ proportion of people living with HIV virus that disclose their status to their sexual partners in a previous related study was $52 \%$ [7], $\mathrm{q}=1-0.52, \mathrm{~d}=$ tolerable error of margin set at $0.05 . \mathrm{Z}=1.96, \mathrm{p}=0.52$, $\mathrm{q}=0.48, \mathrm{n}=384$.

The sample size used for the survey was 422 which took into account incomplete and non-response rate.

\section{Sampling technique}

A simple random sampling technique was used to select $211 \mathrm{HIV}$ male patients from each hospital, who attended the HIV clinics during a 4 week study period from $28^{\text {th }}$ March to $25^{\text {th }}$ April 2016. From the respective hospital's patient clinic attendance register, 18 male patients were randomly selected by balloting during each clinic day. This was carried out for the duration of the study period until 211 patients that met the criteria from each hospital were enrolled, after informed consents were given. Those that did not meet the selection criteria during the balloting process were excluded and replaced through further balloting. HIV patients with debilitating comorbidities were excluded, because at that stage of the illness, disclosure to a family member or caregiver is certain.

\section{Data collection and analysis}

Data was collected using a pretested, semi structured, selfadministered questionnaire and for the respondents who could not read effectively, the questionnaire was interviewer administered. The questionnaire was developed by the researchers and pretested in a HIV clinic within another LGA outside the study area. The content validity was established qualitatively using a panel of five experts who 
were Fellows of the West African College and National College of Physicians. They assessed each question against the intended construct. The questionnaire comprised three sections; section one: the sociodemographic characteristics, section two: sexual behaviour and section three: sero-status disclosure and willingness to disclose.

Data was cleaned and validated manually, and analysed using Software Package for Social Sciences (IBM-SPSS) version 22. Descriptive statistics (frequency tables and summary indices) were generated. Chi Square was used to test association between socio-demographic factors and disclosure status and also, the willingness to disclose. A simple regression model was developed with the socio-demographic factors that had significant associations and binary logistic regression was applied to determine the predictors of disclosure and the willingness to disclose. The $\mathrm{p}$-value was set at $\leq 0.05$ significance level.

\section{Results}

Four hundred and twenty two copies of the questionnaire were distributed but four hundred copies were completely and correctly filled with a response rate of $94.8 \%$.

\section{Socio-demographic and care characteristics of adult male HIV patients receiving care}

The mean age of the respondents was $32.0 \pm 2.0$ years with more than half of the respondents married $(58.8 \%)$ and belonging to the Catholic faith (54.3\%). A majority of the respondents were either traders or artisans $(54.6 \%)$ having a secondary level of education $(57.8 \%)$ and earning a monthly income of more than 20,000 naira (65.0\%) with about half of the respondents living in the rural areas (50.5\%). A majority of the respondents living with family members (57.5\%) were diagnosed to be HIV positive in a hospital (69.5\%) and have been in HIV care for as long as 2-5 years (69.7\%) (Table 1).

\section{Sexual behaviour of adult male HIV patients receiving care}

All the respondents had engaged in sexual intercourse before $(100 \%)$ with their mean age at first sexual intercourse being $16.3 \pm 2$ years. In the last one year, a majority of the respondents had engaged in sexual intercourse (67.3\%) with more than half of them $(55.8 \%)$ having had sex in the last three months. About three quarters of the respondents $(75.8 \%)$ had engaged in sexual intercourse after their HIV diagnosis; with less than two thirds rarely having sex or having sex at least once a month (60.4\%). A majority of the respondents had one sexual partner $(64.5 \%)$ with no new sexual partner after their HIV diagnosis $(70.2 \%)$. Also, a majority of the respondents knew the serostatus of their regular sexual partner $(68.5 \%)$ with two thirds of the respondents that knew, having reported that their partner was HIV positive $(66.8 \%)$. Less than one quarter of the respondents always consistently and correctly use condoms $(23.3 \%)$, with most of the respondents with a positive partner regularly using condoms (81.4\%) and less than two thirds of respondents with a negative partner also, regularly using condoms (61.5\%). Majority of the respondents did not use condoms in their first sexual intercourse $(79.8 \%)$ or in their last sexual encounter (72.2\%). For about three quarters of the respondents, their sexual partners usually suggest the use of condoms before sexual activity (74.3\%) with a majority of the respondents not having sexual satisfaction after the use of condoms (72.0\%). About two thirds of the respondents reported having a decreased level of sexual libido (66.3\%) with just more than half of the respondents reaching orgasm normally (53.3\%) and most, not experiencing any loss of libido (94.5\%). Although for a majority of the respondents, their sexual partners do not consent to sexual intercourse when they want (72.0\%) but most of

\begin{tabular}{|c|c|c|}
\hline Variable & Category & Frequency (\%) $n=400$ \\
\hline \multirow[t]{2}{*}{ Age (years) } & $\leq 30$ & $148(37.0)$ \\
\hline & $31-40$ & $134(33.5)$ \\
\hline \multirow[t]{2}{*}{ Mean age $(32.0 \pm 2.0)$} & $41-50$ & $58(14.5)$ \\
\hline & $>50$ & $60(15.0)$ \\
\hline \multirow[t]{4}{*}{ Religion } & Catholic & $217(54.3)$ \\
\hline & Orthodox & $153(38.2)$ \\
\hline & Pentecostal & $22(5.5)$ \\
\hline & Pagan & $8(2.0)$ \\
\hline \multirow[t]{2}{*}{ Marital status } & Married & $235(58.8)$ \\
\hline & Not married & $165(41.2)$ \\
\hline \multirow[t]{3}{*}{ Educational level } & Tertiary & $148(37.0)$ \\
\hline & Secondary & 231(57.8) \\
\hline & Primary & $21(5.2)$ \\
\hline \multirow[t]{5}{*}{ Occupation } & Artisan & $117(29.3)$ \\
\hline & Traders & $101(25.3)$ \\
\hline & Students & $58(14.5)$ \\
\hline & Teacher & $45(11.3)$ \\
\hline & Others & $79(19.8)$ \\
\hline \multirow{5}{*}{$\begin{array}{l}\text { Monthly Income(Naira) } \\
\text { Median income } \\
(22,000 \pm 5,000)\end{array}$} & $\leq 10,000$ & $97(24.3)$ \\
\hline & $11,000-20,000$ & $43(10.7)$ \\
\hline & $21,000-30,000$ & $72(18.0)$ \\
\hline & $31,000-40,000$ & $118(29.5)$ \\
\hline & $>40,000$ & $70(17.5)$ \\
\hline \multirow[t]{3}{*}{ Place of residence } & Rural & $202(50.5)$ \\
\hline & Urban & $109(27.3)$ \\
\hline & Semi Urban & $89(22.2)$ \\
\hline \multirow[t]{3}{*}{ Living- in arrangement } & Living with family & $230(57.5)$ \\
\hline & Living alone & $99(24.8)$ \\
\hline & Living with others & $71(17.8)$ \\
\hline \multirow[t]{3}{*}{ Place of HIV diagnosis } & Hospital & $278(69.5)$ \\
\hline & Health centre & $68(17.0)$ \\
\hline & Private laboratory & $54(13.5)$ \\
\hline \multirow[t]{2}{*}{ Duration of HIV care } & $\begin{array}{c}6 \text { months - } 1 \text { year } \\
>1-5 \text { years }\end{array}$ & $\begin{array}{c}53(13.3) \\
279(69.7)\end{array}$ \\
\hline & >5years & $68(17.0)$ \\
\hline
\end{tabular}

Table 1: Socio-demographic and care characteristics of adult male HIV patients receiving care.

them, do not complain when they eventually have sex (84.2\%). More than three quarters of the respondents had received sexual education (77.5\%) with all the respondents (100\%) being taught to regularly take their antiretroviral drugs and always use condoms (Table 2).

\section{Sero-status disclosure and willingness to disclose HIV status by adult male HIV patients receiving care}

Majority of the respondents had a regular sexual partner before their HIV diagnosis (83.0\%). The HIV test was recommended to a majority of the respondents by health personnel (74.0\%) and was counselled before the test $(68.8 \%)$. Close to three quarters of the respondents' results were disclosed by their doctors (73.8\%) with a majority of the respondents disclosing this result to someone $(68.3 \%)$ after 2 months of knowing his status (66.3\%). Of the respondents that disclosed, all disclosed their results to their sexual partners (100\%) and in spite of this, most of the respondents were not abandoned by their sexual partners after the disclosure of a positive test (87.5\%) with most of the respondents subsequently encouraging their sexual partners to do a HIV test (88.6\%).

Of the respondents that have not disclosed, a majority were not 
Citation: Iwu AC, Duru CB, Diwe KC, Uwakwe KA, Merenu IA, et al. (2017) Sexual Behaviour, Sero-Status Disclosure and Willingness to Disclose Status among HIV Positive Male Patients Receiving Care in Hospitals in Imo State, Nigeria. J AIDS Clin Res 8: 711. doi: 10.4172/2155-6113.1000711

Page 4 of 10

\begin{tabular}{|c|c|c|}
\hline Variable & Category & Frequency (\%) \\
\hline \multirow[t]{2}{*}{ Have you had sex before? $(n=400)$} & Yes & $400(100.0)$ \\
\hline & No & $0(0.0)$ \\
\hline \multirow{3}{*}{$\begin{array}{l}\text { Age of first sexual intercourse (years) } \\
\text { Mean age is } 16.3 \pm 2 \text { years }(n=400)\end{array}$} & $10-20$ & $216(54.0)$ \\
\hline & $21-30$ & $180(45.0)$ \\
\hline & $31-40$ & $4(1.0)$ \\
\hline \multirow{2}{*}{$\begin{array}{l}\text { Have you had sex in the last } 1 \text { year? } \\
(n=400)\end{array}$} & Yes & $269(67.3)$ \\
\hline & No & $131(32.7)$ \\
\hline \multirow{2}{*}{$\begin{array}{l}\text { Have you had sex in the last } 3 \text { months? } \\
(n=269)\end{array}$} & Yes & $150(55.8)$ \\
\hline & No & 119(44.2) \\
\hline \multirow{2}{*}{$\begin{array}{l}\text { Have you had sex after HIV diagnosis? } \\
(n=400)\end{array}$} & Yes & $303(75.8)$ \\
\hline & No & $97(24.2)$ \\
\hline \multirow{5}{*}{$\begin{array}{l}\text { If yes, how often? } \\
(\mathrm{n}=303)\end{array}$} & Rarely & 123(40.6) \\
\hline & Once a month & $60(19.8)$ \\
\hline & Once a week & $56(18.5)$ \\
\hline & Everyday & $42(13.9)$ \\
\hline & Twice a week & $22(7.3)$ \\
\hline \multirow[t]{2}{*}{ After HIV diagnosis, have you had a new partner(s) $(n=400)$} & Yes & 119(29.8) \\
\hline & No & $281(70.2)$ \\
\hline \multirow{4}{*}{$\begin{array}{l}\text { How many sexual partners do you have? } \\
(n=400)\end{array}$} & One & $258(64.5)$ \\
\hline & Two & $44(11.0)$ \\
\hline & Three & $26(6.5)$ \\
\hline & Multiple & $72(18.0)$ \\
\hline \multirow[t]{2}{*}{ Is your regular partner's Sero-status known? $(n=400)$} & Yes & $274(68.5)$ \\
\hline & No & $126(31.5)$ \\
\hline \multirow[t]{2}{*}{ If yes, what is her status? $(n=274)$} & Positive & 183(66.8) \\
\hline & Negative & $91(33.2)$ \\
\hline \multirow{2}{*}{$\begin{array}{l}\text { If positive, do you use condom regularly? } \\
(\mathrm{n}=183)\end{array}$} & Yes & 149(81.4) \\
\hline & No & $34(18.6)$ \\
\hline \multirow{2}{*}{$\begin{array}{l}\text { If negative, do you use condom regularly? } \\
(\mathrm{n}=91)\end{array}$} & Yes & $56(61.5)$ \\
\hline & No & $35(38.5)$ \\
\hline \multirow[t]{3}{*}{ Generally, how often do you consistently and correctly use condom? $(n=400)$} & Sometimes & $205(51.3)$ \\
\hline & Often & 102(25.5) \\
\hline & Always & $93(23.3)$ \\
\hline \multirow[t]{2}{*}{ Did you use condom in your first sexual intercourse? $(n=400)$} & Yes & $81(20.2)$ \\
\hline & No & $319(79.8)$ \\
\hline \multirow[t]{2}{*}{ Did you use condom in your last sexual intercourse? $(n=400)$} & Yes & $111(27.8)$ \\
\hline & No & $289(72.2)$ \\
\hline \multirow[t]{3}{*}{ Who usually suggests the use of condom? $(n=400)$} & Partner & $297(74.3)$ \\
\hline & Both & $52(13.0)$ \\
\hline & Self & $51(12.7)$ \\
\hline \multirow[t]{2}{*}{ Do you have sexual satisfaction after condom use? $(n=400)$} & Yes & 112(28.0) \\
\hline & No & 288(72.0) \\
\hline Level of sexual activity $(n=400)$ & $\begin{array}{l}\text { Decreased } \\
\text { Same } \\
\text { Increased }\end{array}$ & $\begin{array}{c}265(66.3) \\
78(19.5) \\
57(14.3)\end{array}$ \\
\hline \multirow[t]{2}{*}{ Any loss of libido? } & Yes & $22(5.5)$ \\
\hline & No & $378(94.5)$ \\
\hline How fast do you reach orgasm? $(n=400)$ & Normal as before & 213(53.3) \\
\hline & Faster than before & $111(27.8)$ \\
\hline & Slower than before & $76(19.0)$ \\
\hline Does your partner allow you to have sex with her when you want? $(n=400)$ & Yes & 112(28.0) \\
\hline & No & $288(72.0)$ \\
\hline When eventually having sex, does your partner complain? $(n=400)$ & Yes & $63(15.8)$ \\
\hline & No & $337(84.2)$ \\
\hline Have you had any sexual education? $(n=400)$ & Yes & $310(77.5)$ \\
\hline & No & $90(22.5)$ \\
\hline *If yes, what were you taught $(n=310)$ & Regularly take your drugs & $310(100.0)$ \\
\hline & Always use condoms & $310(100.0)$ \\
\hline & Live normal lives and avoid infecting others & 263(84.8) \\
\hline & Avoid multiple sexual partners & $244(78.7)$ \\
\hline
\end{tabular}

Table 2: Sexual behaviour of adult male HIV patients receiving care. 
Citation: Iwu AC, Duru CB, Diwe KC, Uwakwe KA, Merenu IA, et al. (2017) Sexual Behaviour, Sero-Status Disclosure and Willingness to Disclose Status among HIV Positive Male Patients Receiving Care in Hospitals in Imo State, Nigeria. J AIDS Clin Res 8: 711. doi: 10.4172/2155-6113.1000711

Page 5 of 10

willing to disclose their HIV positive status now (62.2\%) but, of those not willing to disclose now, a majority were willing to disclose in the future (73.4\%). All the respondents $(100 \%)$ were not willing to disclose to any work colleague for fear of discrimination and isolation. Furthermore, more than three quarters of the respondents disclosed were encountering one form of discrimination or the other (78.8\%) with all reporting change in attitude towards them (100\%) and a majority reporting sexual starvation $(71.2 \%)$ as the form of discrimination encountered; even though, a majority reported that, the present level of discrimination has decreased $(76.3 \%)$.

While close to one third of the respondents have not disclosed their HIV positive status (31.7\%), 12\% of the respondents are now willing to disclose their HIV positive status (Table 3 and Figure 1).
Socio demographic factors associated with sero-status disclosure by adult male HIV patients receiving care

The following socio-demographic factors appear to be significantly associated with disclosure of sero-status of the respondents; Age $(\mathrm{p}=0.000)$, religion $(\mathrm{p}=0.000)$, marital status $(\mathrm{p}=0.000)$, educational level $(\mathrm{p}=0.000)$, occupation $(\mathrm{p}=0.000)$, monthly income $(\mathrm{p}=0.000)$, place of residence $(\mathrm{p}=0.000)$ and living-in arrangement $(\mathrm{p}=0.000)$ (Table 4$)$.

Socio demographic factors associated with the willingness to disclose HIV sero-status now by adult male HIV patients receiving care

The following socio-demographic factors appear to be significantly associated with the willingness to disclose sero-status now; Age

\begin{tabular}{|c|c|c|}
\hline Variable & Category & Frequency (\%) \\
\hline \multirow[t]{3}{*}{ Who recommended the HIV test? $(n=400)$} & Health personnel & $296(74.0)$ \\
\hline & Self & $72(18.0)$ \\
\hline & Friends/relatives & $32(8.0)$ \\
\hline \multirow[t]{2}{*}{ Were you counselled before the test? $(n=400)$} & Yes & $275(68.8)$ \\
\hline & No & $125(31.2)$ \\
\hline \multirow{4}{*}{$\begin{array}{l}\text { Who disclosed your result to you? } \\
(n=400)\end{array}$} & Doctor & 295(73.8) \\
\hline & Lab personnel & $61(15.3)$ \\
\hline & NGO staff & $30(7.5)$ \\
\hline & Nurse & $14(3.5)$ \\
\hline \multirow[t]{2}{*}{ Have you disclosed your status to anyone? $(n=400)$} & Yes & $273(68.3)$ \\
\hline & No & $127(31.7)$ \\
\hline \multirow[t]{3}{*}{ *Who did you disclose your status to? $(n=273)$} & Partner & $273(100.0)$ \\
\hline & Relatives & $157(57.5)$ \\
\hline & Both & $97(35.5)$ \\
\hline \multirow[t]{2}{*}{ Before HIV diagnosis, did you have a regular partner? $(n=400)$} & Yes & 332(83.0) \\
\hline & No & $68(17.0)$ \\
\hline \multirow[t]{2}{*}{ If yes, did you encourage her to do the test? $(n=332)$} & Yes & 294(88.6) \\
\hline & No & $38(11.4)$ \\
\hline \multirow[t]{2}{*}{ Did she abandon you when you disclosed your positive status? $(n=273)$} & Yes & $34(12.5)$ \\
\hline & No & 239(87.5) \\
\hline \multirow{5}{*}{$\begin{array}{l}\text { How soon did you disclose your status? } \\
(\mathrm{n}=273)\end{array}$} & $>1$ year & 102(37.4) \\
\hline & $>2$ months- 1 year & $79(28.9)$ \\
\hline & $>1$ week-1 month & $44(16.1)$ \\
\hline & $>1$ month-2 months & 29(10.6) \\
\hline & $>1$ day-1 week & $19(7.0)$ \\
\hline \multirow[t]{2}{*}{ If you have not disclosed, are you now willing to disclose your status? $(n=127)$} & Yes & $48(37.8)$ \\
\hline & No & $79(62.2)$ \\
\hline \multirow[t]{2}{*}{ If no, are willing to disclose in the future? $(n=79)$} & Yes & $58(73.4)$ \\
\hline & No & $21(26.6)$ \\
\hline Are you willing to disclose to your work colleagues? $(n=400)$ & $\begin{array}{l}\text { Yes } \\
\text { No }\end{array}$ & $\begin{array}{c}0(0.0) \\
400(100.0)\end{array}$ \\
\hline \multirow[t]{2}{*}{ *If no, why? $(n=400)$} & Fear of discrimination & $400(100.0)$ \\
\hline & $\begin{array}{l}\text { Fear of isolation } \\
\text { Fear of losing job }\end{array}$ & $\begin{array}{l}400(100.0) \\
74(18.5)\end{array}$ \\
\hline After disclosure, have you received any form of discrimination? $(n=273)$ & $\begin{array}{l}\text { Yes } \\
\text { No }\end{array}$ & $\begin{array}{c}215(78.8) \\
58(21.2)\end{array}$ \\
\hline \multirow[t]{5}{*}{ *If yes, forms of discrimination received? $(n=215)$} & Attitudinal change & $215(100.0)$ \\
\hline & Sexual starvation & $153(71.2)$ \\
\hline & Verbal abuse & $110(51.2)$ \\
\hline & Isolation & $91(42.3)$ \\
\hline & Physical abuse & $36(16.7)$ \\
\hline \multirow[t]{3}{*}{ The present level of discrimination $(n=215)$} & Decreased & $164(76.3)$ \\
\hline & Same & $37(17.2)$ \\
\hline & Increased & $14(6.5)$ \\
\hline
\end{tabular}

${ }^{*}$ Multiple responses

Table 3: Sero-status disclosure and willingness to disclose HIV status by adult Male HIV patients receiving. 
Citation: Iwu AC, Duru CB, Diwe KC, Uwakwe KA, Merenu IA, et al. (2017) Sexual Behaviour, Sero-Status Disclosure and Willingness to Disclose Status among HIV Positive Male Patients Receiving Care in Hospitals in Imo State, Nigeria. J AIDS Clin Res 8: 711. doi: 10.4172/2155-6113.1000711

Page 6 of 10

$(\mathrm{p}=0.000)$ and occupation $(\mathrm{p}=0.012)$. On the other hand, the associations of religion, marital status, educational level, monthly income, place of residence and living in arrangements were not statistically significant with the willingness to disclose ( $\mathrm{p}>0.05)$ (Table 5).

\section{Predictors of HIV sero-status disclosure by adult male HIV patients receiving care}

Respondents who are above 30 years were significantly more likely

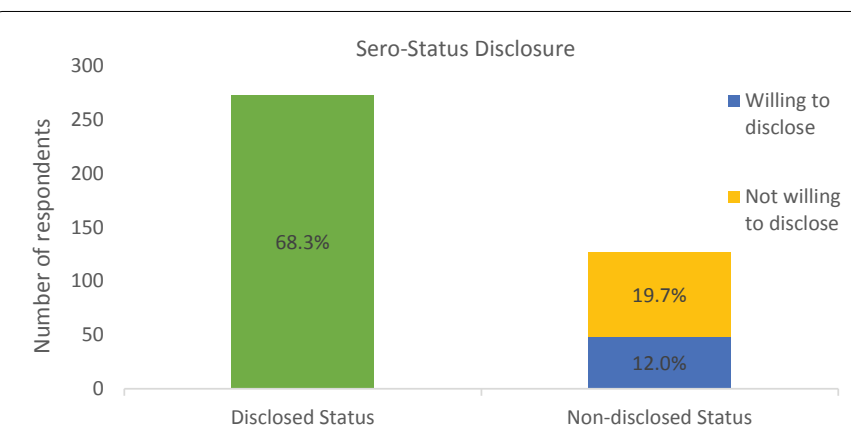

Figure 1: Sero-status disclosure of adult male HIV patients receiving care from hospitals in Imo state. to have disclosed their HIV sero-status when compared to those aged 30 years or less (OR: 6.04; 3.813-9.558, $\mathrm{p}=0.000$ ). Respondents that practice orthodox Christian religion were significantly less likely to have disclosed their HIV sero-status when compared to pagans (OR: 0.13; $0.015-1.057, \mathrm{p}=0.032$ ). Respondents that are married were significantly more likely to have disclosed their HIV sero-status when compared to those that are not married (OR: 3.24; 2.091-5.013, $\mathrm{p}=0.000$ ). Respondents that are artisans and traders were significantly more likely to have disclosed their HIV sero-status when compared to others that were not students or teachers (OR: 2.04; 1.092-3.815, $\mathrm{p}=0.024$ ) and (OR: 8.22; 3.369-20.066, $\mathrm{p}=0.000$ ) respectively; but respondents that are students were significantly less likely to have disclosed their HIV sero-status when compared to others that were not artisans, traders or teachers (OR: 0.23; 0.112-0.486, $\mathrm{p}=0.000$ ). Respondents that earn a monthly income of $\mathrm{N} 40,000$ ( $\$ 110)$ or less were significantly more likely to have disclosed their HIV sero-status when compared to those than earn more than N40, 000 (OR: 6.93; 3.942-12.190, $\mathrm{p}=0.000$ ). Respondents that live in urban and semi-urban areas were significantly more likely to have disclosed their HIV sero-status when compared to those that live in rural areas (OR: 16.61; 9.007-30.648, $\mathrm{p}=0.000$ ) and (OR: $2.21 ; 1.248-3.918, \mathrm{p}=0.006$ ), respectively. Respondents that live with family members and with other people were significantly more

\begin{tabular}{|c|c|c|c|c|c|c|}
\hline Variable & $\begin{array}{l}\text { Sero-status } \\
\text { Disclosed (\%) }\end{array}$ & \begin{tabular}{|c|} 
Sero-status \\
Not Disclosed (\%)
\end{tabular} & Total (\%) & $X^{2}$ & df & p-value \\
\hline $\begin{array}{l}\text { Age (yrs) } \\
\leq 30 \\
31-40 \\
41-50 \\
>50 \\
\text { Total }\end{array}$ & $\begin{array}{c}65(43.9) \\
105(78.4) \\
54(93.1) \\
49(81.7) \\
273(68.3)\end{array}$ & $\begin{array}{c}83(56.1) \\
29(21.6) \\
4(6.9) \\
11(18.3) \\
127(31.8)\end{array}$ & $\begin{array}{r}148(100) \\
134(100) \\
58(100) \\
60(100) \\
400(100)\end{array}$ & 68.27 & 3 & $0.000^{*}$ \\
\hline $\begin{array}{l}\text { Religion } \\
\text { Catholic } \\
\text { Orthodox } \\
\text { Pentecostal } \\
\text { Pagan } \\
\text { Total }\end{array}$ & $\begin{array}{c}179(82.5) \\
72(47.1) \\
15(68.2) \\
7(87.5) \\
273(68.3)\end{array}$ & $\begin{array}{c}38(17.5) \\
81(52.9) \\
7(31.8) \\
1(12.5) \\
127(31.8)\end{array}$ & $\begin{array}{c}217(100) \\
153(100) \\
22(100) \\
8(100) \\
400(100)\end{array}$ & 53.38 & 3 & $0.000^{*}$ \\
\hline $\begin{array}{l}\text { Marital Status } \\
\text { Married } \\
\text { Not married } \\
\text { Total }\end{array}$ & $\begin{array}{c}185(78.7) \\
88(53.3) \\
273(68.3)\end{array}$ & $\begin{array}{r}50(21.3) \\
77(46.7) \\
127(31.8)\end{array}$ & $\begin{array}{l}235(100) \\
165(100) \\
400(100)\end{array}$ & 28.84 & 1 & $0.000^{*}$ \\
\hline $\begin{array}{l}\text { Educational level } \\
\text { Tertiary } \\
\text { Secondary } \\
\text { Primary } \\
\text { Total } \\
\text { Occupation } \\
\text { Artisan } \\
\text { Traders } \\
\text { Students } \\
\text { Teacher } \\
\text { Others } \\
\text { Total }\end{array}$ & $\begin{array}{r}80(54.1) \\
178(77.1) \\
15(71.4) \\
273(68.3) \\
\\
90(76.9) \\
94(93.1) \\
16(27.6) \\
24(53.3) \\
49(62.0) \\
273(68.3)\end{array}$ & $\begin{array}{c}68(45.9) \\
53(22.9) \\
6(28.6) \\
127(31.8) \\
\\
27(23.1) \\
7(6.9) \\
42(72.4) \\
21(46.7) \\
30(38.0) \\
127(31.8)\end{array}$ & $\begin{array}{r}148(100) \\
231(100) \\
21(100) \\
400(100) \\
\\
117(100) \\
101(100) \\
58(100) \\
45(100) \\
79(100) \\
400(100)\end{array}$ & $\begin{array}{l}22.13 \\
83.07\end{array}$ & 4 & $0.000^{*}$ \\
\hline $\begin{array}{l}\text { Monthly Income } \\
\leq 40,000 \\
>40,000 \\
\text { Total }\end{array}$ & $\begin{array}{c}251(76.1) \\
22(31.4) \\
273(68.3)\end{array}$ & $\begin{array}{r}79(23.9) \\
48(68.6) \\
127(31.8)\end{array}$ & $\begin{array}{c}330(100) \\
70(100) \\
400(100)\end{array}$ & 53.09 & 1 & $0.000^{*}$ \\
\hline $\begin{array}{l}\text { Place of residence } \\
\text { Rural } \\
\text { Urban } \\
\text { Semi Urban } \\
\text { Total }\end{array}$ & $\begin{array}{c}40(36.7) \\
183(90.6) \\
50(56.2) \\
273(68.3)\end{array}$ & $\begin{array}{c}69(63.3) \\
19(9.4) \\
39(43.8) \\
127(31.8)\end{array}$ & $\begin{array}{c}109(100) \\
202(100) \\
89(100) \\
400(100)\end{array}$ & 102.60 & 2 & $0.000^{*}$ \\
\hline $\begin{array}{l}\text { Living-in arrangement } \\
\text { Living with family } \\
\text { Living alone } \\
\text { Living with others } \\
\text { Total }\end{array}$ & $\begin{array}{r}170(73.9) \\
44(44.4) \\
59(83.1) \\
273(68.3)\end{array}$ & $\begin{array}{r}60(26.1) \\
55(55.6) \\
12(16.9) \\
127(31.8)\end{array}$ & $\begin{array}{r}230(100) \\
99(100) \\
71(100) \\
400(100)\end{array}$ & 36.52 & 2 & $0.000^{*}$ \\
\hline
\end{tabular}

*significant 
likely to have disclosed their HIV sero-status when compared to those that live alone (OR: $3.54 ; 2.162-5.803, \mathrm{p}=0.000)$ and (OR: 6.15; 2.943$12.836, \mathrm{p}=0.000)$, respectively (Table 6).

\section{Predictors of the willingness to disclose HIV sero-status now by adult male HIV patients receiving care}

Respondents who are above 30 years were significantly more likely to be willing to disclose their HIV sero-status now when compared to those aged 30 years or less (OR: 6.51; 2.907-14.591, $\mathrm{p}=0.000$ ).

Respondents who were artisans, were significantly more likely to be willing to disclose their HIV sero-status now when compared to others that were not students or teachers (OR: 4.02; 1.403-11.508, $\mathrm{p}=0.008$ ) (Table 7).

\section{Discussion}

This study determined sexual behaviour, the levels of sero-status disclose and willingness to disclose; and their socio-demographic determinants among HIV positive male patients attending two HIV clinics in Imo State. It revealed that adult HIV male patients engaged in risky sexual behavioural practices and had a relatively low HIV status disclosure rate; and of those not disclosed, only a smaller proportion were willing to disclose now or in the future. It was further revealed that, there were significant relationships between their socio-demographic characteristics and HIV positive status disclosure and their willingness to disclose.
Risky sexual behaviour is pivotal to the transmission of HIV/AIDS especially among confirmed HIV patients who have not disclosed their status to their sexual partners $[4,5,13]$. Though it has been observed that the initiation of ART may be associated with increased risky sexual behaviour and therefore, increased risk of transmission [22], it has also been observed that initiation and adherence to ART is associated with remarkable reduction in the risk of transmission of HIV/AIDS by reducing viral loads [23]. Hence, it is still very important that HIV patients on ART engage in non-risky sexual behavioural practices not only to protect their partners but also to protect themselves from the introduction of possible strains of HIV that may be resistant to their current drug regimen [24].

In the present study, the risk of transmission appear to be elevated when taken into consideration, that only less than one quarter of the respondents always consistently and correctly use condoms with about three quarters of the respondents having engaged in sexual intercourse after their HIV diagnosis and more than $20 \%$ of the respondents having sex every day or at least twice a week; and also, with about $35 \%$ of the respondents having two or more sexual partners. This low use of condoms, was similarly observed in some studies done in Nigeria; among HIV patients on ART, where about $84 \%$ of respondents either sometimes or never used condoms with their spouses [25] and within the general population, where as low as $25 \%$ consistently use condoms [26]. On the contrary, a study in South West Nigeria among HIV patients on ART [27] reported a consistent and correct condom use rate as high as $75 \%$.

\begin{tabular}{|c|c|c|c|c|c|c|}
\hline Variable & $\begin{array}{l}\text { Willingness to } \\
\text { Disclose (\%) }\end{array}$ & $\begin{array}{c}\text { Non-willingness to } \\
\text { Disclose (\%) }\end{array}$ & Total (\%) & $x^{2}$ & Df & p-value \\
\hline $\begin{array}{l}\text { Age (yrs) } \\
\leq 30 \\
>30 \\
\text { Total }\end{array}$ & $\begin{array}{l}19(22.9) \\
29(65.9) \\
48(37.8)\end{array}$ & $\begin{array}{l}64(77.1) \\
15(34.1) \\
79(62.2)\end{array}$ & $\begin{array}{r}83(100) \\
44(100) \\
127(100)\end{array}$ & 22.63 & 1 & $0.000^{*}$ \\
\hline $\begin{array}{l}\text { Religion } \\
\text { Catholic } \\
\text { Non-Catholic } \\
\text { Total }\end{array}$ & $\begin{array}{l}16(42.1) \\
32(36.0) \\
48(37.8)\end{array}$ & $\begin{array}{l}22(57.9) \\
57(64.0) \\
79(62.2)\end{array}$ & $\begin{array}{c}38(100) \\
89(100) \\
127(100)\end{array}$ & 0.43 & 1 & 0.513 \\
\hline $\begin{array}{l}\text { Marital Status } \\
\text { Married } \\
\text { Not married } \\
\text { Total }\end{array}$ & $\begin{array}{l}17(34.0) \\
31(40.3) \\
48(37.8)\end{array}$ & $\begin{array}{l}33(66.0) \\
46(59.7) \\
79(62.2)\end{array}$ & $\begin{array}{r}50(100) \\
77(100) \\
127(100)\end{array}$ & 0.51 & 1 & 0.477 \\
\hline $\begin{array}{l}\text { Educational level } \\
\text { Tertiary } \\
\text { Secondary or less } \\
\text { Total }\end{array}$ & $\begin{array}{l}27(39.7) \\
21(35.6) \\
48(37.8)\end{array}$ & $\begin{array}{l}41(60.3) \\
38(64.4) \\
79(62.2)\end{array}$ & $\begin{array}{r}68(100) \\
59(100) \\
127(100)\end{array}$ & 0.23 & 1 & 0.634 \\
\hline $\begin{array}{l}\text { Occupation } \\
\text { Artisan } \\
\text { Students } \\
\text { Teacher } \\
\text { Others } \\
\text { Total }\end{array}$ & $\begin{array}{l}17(63.0) \\
11(26.2) \\
9(42.9) \\
11(29.7) \\
48(37.8)\end{array}$ & $\begin{array}{l}10(37.0) \\
31(73.8) \\
12(57.1) \\
26(70.3) \\
79(62.2)\end{array}$ & $\begin{array}{r}27(100) \\
42(100) \\
21(100) \\
37(100) \\
127(100)\end{array}$ & 0.93 & 3 & $0.012^{*}$ \\
\hline $\begin{array}{l}\text { Monthly Income } \\
\leq 40,000 \\
>40,000 \\
\text { Total }\end{array}$ & $\begin{array}{l}27(34.2) \\
21(43.8) \\
48(37.8)\end{array}$ & $\begin{array}{l}52(65.8) \\
27(56.3) \\
79(62.2)\end{array}$ & $\begin{array}{r}79(100) \\
48(100) \\
127(100)\end{array}$ & 1.16 & 1 & 0.281 \\
\hline $\begin{array}{l}\text { Place of residence } \\
\text { Rural } \\
\text { Urban } \\
\text { Semi Urban } \\
\text { Total }\end{array}$ & $\begin{array}{c}25(36.2) \\
7(36.8) \\
16(41.0) \\
48(37.8)\end{array}$ & $\begin{array}{l}44(63.8) \\
12(63.2) \\
23(59.0) \\
79(62.2)\end{array}$ & $\begin{array}{r}69(100) \\
19(100) \\
39(100) \\
127(100)\end{array}$ & 0.25 & 2 & 0.882 \\
\hline $\begin{array}{l}\text { Living-in arrangement } \\
\text { Living with family/others } \\
\text { Living alone } \\
\text { Total }\end{array}$ & $\begin{array}{l}30(41.7) \\
18(32.7) \\
48(37.8)\end{array}$ & $\begin{array}{l}42(58.3) \\
37(67.3) \\
79(62.2)\end{array}$ & $\begin{array}{r}72(100) \\
55(100) \\
127(100)\end{array}$ & 1.06 & 1 & 0.303 \\
\hline
\end{tabular}

*significant

Table 5: Socio demographic factors associated with the willingness to disclose HIV sero-status now by adult Male HIV patients receiving care. 


\begin{tabular}{|c|c|c|c|}
\hline Variable & OR (estimate) & 95\%(Cl) & $\mathrm{p}$-value \\
\hline $\begin{array}{l}\text { Age (years) } \\
\leq 30\end{array}$ & 1.00 & - & - \\
\hline$>30$ & 6.04 & $3.813-9.558$ & $0.000^{*}$ \\
\hline Pagan & 1.00 & - & - \\
\hline Catholic & 0.67 & $0.080-5.631$ & 1.000 \\
\hline Orthodox & 0.13 & $0.015-1.057$ & $0.032^{*}$ \\
\hline Pentecostal & 0.31 & $0.031-2.991$ & 0.391 \\
\hline Not married & 1.00 & - & - \\
\hline Married & 3.24 & $2.091-5.013$ & $0.000^{*}$ \\
\hline Secondary or less & 1.00 & - & - \\
\hline Tertiary & 0.36 & $0.233-0.556$ & $0.000^{*}$ \\
\hline Others & 1.00 & - & - \\
\hline Artisan & 2.04 & $1.092-3.815$ & $0.024^{*}$ \\
\hline Traders & 8.22 & 3.369-20.066 & $0.000^{*}$ \\
\hline Students & 0.23 & $0.112-0.486$ & $0.000^{*}$ \\
\hline Teacher & 0.70 & $0.333-1.468$ & 0.345 \\
\hline \multicolumn{4}{|l|}{ Monthly Income } \\
\hline$>40,000(\$ 110)$ & 1.00 & - & - \\
\hline$\leq 40,000(\$ 110)$ & 6.93 & $3.942-12.190$ & $0.000^{*}$ \\
\hline \multicolumn{4}{|c|}{ Place of Residence } \\
\hline Rural & 1.00 & - & - \\
\hline Urban & 16.61 & $9.007-30.648$ & $0.000^{*}$ \\
\hline Semi Urban & 2.21 & $1.248-3.918$ & $0.006^{*}$ \\
\hline \multicolumn{4}{|c|}{ Living-in arrangement } \\
\hline Living alone & 1.00 & - & - \\
\hline Living with family & 3.54 & $2.162-5.803$ & $0.000^{*}$ \\
\hline Living with others & 6.15 & $2.943-12.836$ & $0.000^{*}$ \\
\hline
\end{tabular}

Table 6: Predictors of HIV sero-status disclosure by adult male HIV patients receiving care.

\begin{tabular}{|l|c|c|c|c|c|}
\hline Variable & \multicolumn{3}{|c|}{ OR (estimate) $\mathbf{9 5 \%}(\mathbf{C l})$ p-value } & $95 \%(\mathrm{Cl})$ & p-value \\
\hline Age (years) & & & & & \\
\hline$\leq 30$ & 1.00 & - & - & & \\
\hline$>30$ & 6.51 & $2.907-14.591$ & $\mathbf{0 . 0 0 0 ^ { * }}$ & & \\
\hline Occupation & & & & & \\
\hline Artisan & 1.00 & - & - & & \\
& 4.02 & $1.403-11.508$ & $\mathbf{0 . 0 0 8 ^ { * }}$ & & \\
\hline Students & 0.84 & $0.313-2.246$ & 0.729 & & \\
\hline Teacher & 1.77 & $0.581-5.408$ & 0.313 & & \\
\hline
\end{tabular}

Table 7: Predictors of the willingness to disclose sero-status now by adult male HIV patients receiving care.

With respect to engaging in sexual activity and having multiple sexual partners, the present study was similar to the study by Berniera et al. [28] who reported that $23 \%$ of the male participants stopped having sex after HIV diagnosis and also, according to Denue et al. [25] who reported that, about $39 \%$ of HIV patients on ART for a length of time, had multiple sexual partners. Sullivan in his study [29] reported that, as the number of sex partners for men increases, the likelihood of disclosure will decrease. Furthermore, our study was not consistent with a review of studies conducted in Africa by Kennedy et al. [30], where it was observed that a majority of HIV patients on ART abstained from sexual activity. This risky sexual behavioural tendency observed among our study participants may be due to the decreased perception of their risk of HIV infection as a result of their access to effective ART [31]; and this may also be contributing to the level of disclosure observed in this study.

In the present study, the relatively low level of disclosure of
HIV status among the respondents was similarly observed in some studies across Africa; Mali, Burkina Faso, Uganda, Zimbabwe, Togo and Nigeria [32-36]. On the other hand, there were other studies in Ethiopia and Uganda that reported relatively high disclosure rates $[4,8,19]$. It was also observed in the present study, that more than one third of those not disclosed, indicated their willingness to disclose now and of those not willing to disclose now, close to three quarters were willing to disclose in the future. This observed willingness of the respondents, does not necessarily translate to disclosure, as reported in a Nigerian study [37], where there was no association between the study participants willingness to disclose and their partners getting tested in spite of the fact that, most of the participants who tested positive to HIV indicated their willingness to disclose.

This different levels of disclosure rates may be related to the varying levels of stigma and discrimination still associated with HIV infection existing within and across regions, within families and especially in the work place; where all the respondents in present study indicated that they are not willing to disclose to any colleague at work for fear of discrimination and isolation and also, where a majority reported having experienced one form of discrimination or the other with all of the respondents indicating that, attitudinal change towards them was the most common. This change in attitude translates to discrimination, isolation, abandonment, abuse and so on and therefore, the fear of this happening, not only is the cause of non-disclosure, but could also be contributing to the delay in disclosure. This has also been observed in the present study, where two thirds of the respondents only disclosed their HIV positive status after a couple of months to more than one year of being diagnosed. This delay in disclosure, may also be attributed to some degree, to the lack of pre-test counselling as observed in the present study, where close to one third of the respondents did not receive pre-test counselling. According to some studies in Ethiopia [38,39], discussions with the patient before HIV testing and pre-test counselling were significantly associated with disclosure of a HIV positive status. Furthermore, after a HIV diagnosis, the patient goes through a process of adjustments before finally arriving at a decision to disclose. Hence, pre-test counselling or discussions with the patient before a HIV test, helps to quicken this process of adjustments and therefore, encourages early disclosure. A delay in disclosure is as important as non-disclosure with respect to public health, where delay in disclosure provides a window for an increased risk of transmission of infection to an unknowing sexual partner. This lack of awareness, denies the sexual partner the opportunity to consciously practice safe sex or even abstinence. This is probably exemplified in the present study, where close to three quarters of the respondents reported sexual starvation as the form of discrimination which was experienced after disclosure of their HIV positive status.

Generally, discrimination of people living with HIV appears to be decreasing though still high [2], it was observed in the present study, that there were more than three quarters of the respondents who indicated that, the present levels of discrimination have decreased; and also, that they were not abandoned by their spouses after disclosure of their HIV positive status. This may be attributed to the economic dependence on men and gender inequality in our environment and probably, also due to the increased level of public health awareness efforts with respect to preventive and effective control measures and the availability of effective treatments associated with improved quality of life; and furthermore, in some cases, the enactment of nondiscriminating laws. 
In the present study, more socio-demographic factors appear to be determinants for disclosure, when compared to the number of factors observed to determine the willingness to disclose. For instance, it was observed that being an artisan or more than 30 years old were the only determinants for the willingness to disclose. On the other hand, there were multiple socio-demographic factors that were determinants for disclosure in the present study, which were also similarly observed in other studies. These determinants were; being in an older age group [32,40,41], married [5,16,27,35,38,41], not religious [42] having a higher level of education $[32,38,41,43]$ and residing in an urban or semi-urban place [43]. Notwithstanding, some of these socio-demographic determinants for disclosure were on the contrary, not also observed in other studies such as; being in an older age group [5,35], being married [33,40], not religious [32], level of education [5,35,40], occupation [40,41], lower level of income [41] and residing in an urban or semi-urban place [35]. Therefore, it can be further observed that these relationships with disclosure appear to vary within and across studies which is probably due to the influence of a number of peculiar factors and circumstances that motivate disclosure such as the target of disclosure, HIV care and also, the enabling social and environmental conditions that exists.

\section{Conclusion}

Engaging in risky sexual behaviour within the context of nondisclosure among HIV patients on ART remains an important public health issue. So focusing and increasing preventive efforts; and implementing appropriate interventions in the health care facilities that encourage immediate partner disclosure and linkage to care especially of newly diagnosed of HIV positive individuals, will further prevent HIV transmission and reduce the burden of HIV infections within the families and the communities at large.

Furthermore, to be successful in our efforts of HIV prevention with respect to facilitating disclosure, it is important to design and implement strategies that are tailored to the specific circumstances of the individual which must take into cognisance their sociodemographic characteristics.

\section{Acknowledgement}

We thank all the participants in this study, the research assistants who helped during the data collection and the patient care support from Centre for Clinical Care and Research, Nigeria (CCCRN).

\section{References}

1. Global AIDS Response Progress Reporting (GARPR) (2016). UNAIDS estimates 2016. WHO.

2. UNAIDS Prevention gap report (2016) UNAIDS.

3. Joint United Nations Programme on HIVIAIDS (UNAIDS) (1999) Sexual behavioural change for HIV: Where have theories taken us? UNAIDS Geneva, Switzerland 1999. UNAIDS

4. Deribe K, Woldemichael K, Wondafrash M, Haile A, Amberbir A (2008) Disclosure experience and associated factors among HIV positive men and women clinical service users in Southwest Ethiopia. BMC Public Health 8: 81.

5. Amoran OE (2012) Predictors of disclosure of sero-status to sexual partners among people living with HIVIAIDS in Ogun State, Nigeria. Niger J Clin Pract 15: $385-390$.

6. Medley A, Garcia-Moreno C, McGill S, Maman S (2004) Rates, barriers and outcomes of HIV sero-status disclosure among women in developing countries: Implications for prevention of mother-to-child transmission programmes. Bull World Health Organ 82: 299-307.

7. World Health Organization (2003) A review paper; gender dimensions of HIV status disclosure to sexual partners: Rates, barriers and outcomes. World Health Organization, Geneva.
8. Seid M, Wasie B, Admassu M (2012) Disclosure of HIV positive result to a sexual partner among adult clinical service users in Kemissie district, northeast Ethiopia. Afr J Reprod Health 16: 97-104.

9. Stein MD, Freedberg KA, Sullivan LM, Savetsky J, Levenson S M, et al. (1998) Sexual ethics: Disclosure of HIV-positive status to partners. Arch Intern Med 158: 253-257.

10. Stutterheim SP, Shiripinda I, Bos AER, Pryor JB, de Bruin M, et al. (2011) HIV status disclosure among HIV-positive African and Afro-Caribbean people in the Netherlands. AIDS Care 23: 195-205.

11. Greeff M, Phetlhu R, Makoae LN, Dlamini PS, Holzemer WL, et al. (2008) Disclosure of HIV status: experiences and perceptions of persons living with HIV/ AIDS and nurses involved in their care in Africa. Qual Health Res 18: 311-324.

12. Loubiere S, Peretti-Watel P, Boyer S, Blanche J, Abega S, et al. (2009) HIV disclosure and unsafe sex among HIV-infected women in Cameroon: Results from the ANRS-EVAL Study. Soc Sci Med 69: 885-891.

13. Pinkerton SD, Galletly CL (2007) Reducing HIV transmission risk by increasing serostatus disclosure: A mathematical modeling analysis. AIDS Behav 11: 698705 .

14. UNAIDS (2011) Global plan towards the elimination of new HIV infections among children by 2015 and keeping their mothers alive: 2011-2015. Joint United Nations Programme on HIVIAIDS, Geneva, Switzerland.

15. Strachan ED, Bennett WR, Russo J, Roy-Byrne PP (2007) Disclosure of HIV status and sexual orientation independently predicts increased absolute CD4 cell counts over time for psychiatric patients. Psychosom Med 69: 74-80.

16. King R, Katuntu D, Lifshay J, Packel L, Batamwita R, et al. (2008) Processes and outcomes of HIV serostatus disclosure to sexual partners among people living with HIV in Uganda. AIDS Behav 12: 232-243.

17. Neville Miller A, Rubin DL (2007) Factors leading to self-disclosure of a positive HIV diagnosis in Nairobi, Kenya: People living with HIVIAIDS in the SubSahara. Qual Health Res 17: 586-598.

18. Rice E, Comulada S, Green S, Arnold EM, Rotheram-Borus MJ (2009) Differential disclosure across social network ties among women living with HIV. AIDS Behav 13: 1253-1261.

19. Ssali SN, Atuyambe L, Tumwine C, Segujja E, Nekesa N, et al. (2010) Reasons for disclosure of HIV status by people living with HIVIAIDS and in HIV care in Uganda: An exploratory study. AIDS Patient Care STDS 24: 675-681.

20. National Population Commission (NPC) (2006) Federal Republic of Nigeria 2006 population and housing census: Priority table volume III.

21. Cochran WG (1963) Sampling technique (2nd ed.) John Wiley and sons Inc., New York.

22. Wilson TE, Gore ME, Greenbatt R, Cohen M, Minkoff H, et al. (2004) Changes in sexual behaviour among HIV-Infected women after initiation of HAART. Am J Public Health 94: 1141-1145.

23. Cohen MS, Chen YQ, McCauley M, Gamble T, Hosseinipour MC, et al. (2011) Prevention of HIV-1 infection with early antiretroviral therapy. N Engl J Med 365: 493-505.

24. Pomerantz RJ (1999) Primary HIV-1 resistance: A new phase in the epidemic? JAMA 282: 1177-1179.

25. Denue B, Kwayabura S, Bukbuk D, Inuwa U, Ajayi B (2014) Evaluation of condom use and associated factors among adult HIV clients in Maiduguri, North Eastern Nigeria: A comparative cross sectional study. World J AIDS 4: 169-177.

26. Federal Ministry of Health (2010) HIV/STI integrated biological and behavioural surveillance survey 2010. Federal Ministry of Health Abuja, Nigeria.

27. Adebayo AM, llesanmi OS, Omotoso BA, Ayodeji OO, Kareem AO, et al. (2014) Disclosure to sexual partner and condom use among HIV positive clients attending ART clinic at a tertiary health facility in South West Nigeria Pan Afr Med J 18: 245.

28. Berniera A, Lefèvrea M, Henrya E, Verdesb L, Acostac M, et al. (2016) HIV seropositivity and sexuality: Cessation of sexual relations among men and women living with HIV in five countries. AIDS CARE 28: 26-31.

29. Sullivan KM (2005) Male self-disclosure of HIV-positive serostatus to sex partners: A review of the literature. J Assoc Nurses AIDS Care 16: 33-47. 
Citation: Iwu AC, Duru CB, Diwe KC, Uwakwe KA, Merenu IA, et al. (2017) Sexual Behaviour, Sero-Status Disclosure and Willingness to Disclose Status among HIV Positive Male Patients Receiving Care in Hospitals in Imo State, Nigeria. J AIDS Clin Res 8: 711. doi: 10.4172/2155-6113.1000711

30. Kennedy C, O'Reilly K, Medley A, Sweat M (2007) The impact of HIV treatment on risk behaviour in developing countries: A systematic review. AIDS Care 19: 707-720.

31. Cassell MM, Halperin DT, Shelton JD, Stanton D (2006) Risk compensation: The Achilles' heel of innovations in HIV prevention? BMJ 332: 605-607.

32. Ndiaye C, Boileau C, Zunzunegui MV, Koala S, Aboubacrine SA, et al. (2008) Gender-related factors influencing HIV sero-status disclosure in patients receiving HAART in West Africa. World Health Popul 10: 43-54.

33. Osinde MO, Kakaire O, Kaye DK (2012) Factors associated with disclosure of HIV serostatus to sexual partners of patients receiving HIV care in Kabale, Uganda. Int J Gynaecol Obstet 118: 61-64

34. Kangwende RA, Chirenda J, Mudyiradima RF (2009) HIV status disclosure among people living with HIVIAIDS at FASO, Mutare, Zimbabwe. Cent Afr J Med 55: 1-7.

35. Yaya I, Saka B, Landoh DE, Patchali PM, Patassi AA, et al. (2015) HIV status disclosure to sexual partners, among people living with HIV and AIDS on antiretroviral therapy at Sokodé Regional Hospital, Togo. PLoS ONE 10: e0118157.

36. Titilope AA, Adediran A, Umeh C, Akinbami A, Unigwe O, et al. (2011) Psychosocial impact of disclosure of HIV serostatus in heterosexual relationship at the Lagos University teaching hospital, Nigeria. Niger Med J 52: 55-59.
37. Onovo AA, Nta IE, Onah AA, Okolo CA, Aliyu A, et al. (2015) Partner HIV serostatus disclosure and determinants of sero-discordance among prevention of mother to child transmission clients in Nigeria. BMC Public Health 15: 827

38. Genet M, Sebsibie G, Gultie T (2015) Disclosure of HIV seropositive status to sexual partners and its associated factors among patients attending antiretroviral treatment clinic follow up at Mekelle Hospital, Ethiopia: A cross sectional study. BMC Res Notes 8: 109.

39. Alemayehu M, Aregay A, Kalayu A, Yebyo H (2014) HIV disclosure to sexual partner and associated factors among women attending ART clinic at Mekelle hospital, Northern Ethiopia. BMC Public Health 14: 746.

40. Yonah G, Fredrick F, Leyna G (2014) HIV serostatus disclosure among people living with HIVIAIDS in Mwanza, Tanzania. AIDS Res Ther 11: 5.

41. Kiula ES, Damian DJ, Msuya SE (2013) Predictors of HIV serostatus disclosure to partners among HIV-positive pregnant women in Morogoro, Tanzania. BMC Public Health 13: 433.

42. Préau M, Bouhnik AD, Roussiau N, Lert F, Spire B (2008) Disclosure and religion among people living with HIVIAIDS in France. AIDS Care 20: 521-526.

43. Hardon A, Gomez GB, Vernooij E, Desclaux A, Wanyenze RK, et al. (2013) Do support groups members disclose less to their partners? The dynamics of HIV disclosure in four African countries. BMC Public Health 13: 589. 